\title{
Determination of the homogeneity of the Ag-Au bimetallic alloy thin films by means of a micro beam X-Ray fluorescence setup with using elemental composition
}

\author{
Ag-Au bimetalik alaşımlı ince filmlerin mikro-X ışını flüoresans sistemi ile homojenliğinin \\ belirlenmesi
}

\author{
Oğuz Kağan KÖKSAL ${ }^{* 1,2, a}$ \\ ${ }^{1}$ Department of Electrical-Electronics Engineering, Faculty of Engineering, Adlyaman University, 02040, Adryaman, Turkey \\ ${ }^{2}$ Department of Medical Physics and Biophysics, Faculty of Physics and Applied Computer Science, AGH University Science and \\ Technology, Krakow, Poland
}

• Geliş tarihi / Received: 09.02.2021 • • Düzeltilerek geliş tarihi / Received in revised form: 20.05.2021 • Kabul tarihi / Accepted: 24.05 .2021

\begin{abstract}
The goal of this work is to research the effect of different Au-Ag ratios on the homogeneity of Au-Ag bimetal alloys. Thin films of silver $(\mathrm{Ag})$-gold $(\mathrm{Au})$ bimetal alloy were produced using Vaksis Thermal Evaporator system and quartz crystal microbalance detector at different gold (Au) additive ratios. Micro beam X-Ray fluorescence spectrometer system was used to calculate the homogeneity of bimetallic $\mathrm{Ag}$-Au alloy thin films and to calculate production $\mathrm{Au}-\mathrm{Ag}$ ratios with different concentration values. It is seen that the calculated ratios and production value are in good agreement.
\end{abstract}

Keywords: Bimetallic alloy, Homogeneity, Micro XRF

$\ddot{O} z$

$\mathrm{Bu}$ araştırmanın amacl, farklı Ag-Au oranlarının Ag-Au bimetal alaşımlarının homojenliği üzerindeki etkisini araştırmaktır. Gümüş (Ag) -altın (Au) bimetal alaşımlı ince filmler, Vaksis Termal Evaporatör sistemi ve farklı altın (Au) katkı oranlarında kuvars kristal mikro terazi dedektörü kullanılarak üretildi. Microbeam X-Ray flüoresans spektrometre sistemi, bimetalik Au-Ag alaşımlı ince filmlerin homojenliğini hesaplamak ve farklı konsantrasyon değerleri ile üretim Au-Ag oranlarını hesaplamak için kullanıldı. Hesaplanan oranlar ile üretim değerinin uyumlu olduğu görülmektedir.

Anahtar Kelimeler: Bimetallic alloy, Homogeneity, Micro XRF

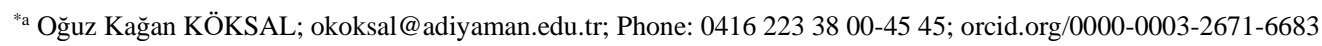




\section{Introduction}

Bimetallic Au-Ag alloys have led to significant advances in various fields such as bio sensing, drug delivery, catalytic fields optics and electronics due to the possibility of tuning the optical and electronic (and thus catalytic) properties. In biomedical fields; it has attracted the attention of interdisciplinary scientists when it exhibits interesting electronic and structural properties (Ispasoiu et al., 2000; Jana and Peng, 2003; Mulvaney et al., 1993; Sun and Xia, 2002; Wang et al., 2001).

Micro beam X-ray fluorescence is a powerful analytical method and a non-destructive elemental analysis method a wide range for metal research, stratified materials, environmental and biological specimens. Besides it is used for the investigation of archaeology and forensic fields (Kanngiesser et al., 2005; Lin et al., 2008; Mantouvalou et al., 2010; Nakano and Tsuji, 2010; Tsuji and Nakano, 2007). The samples are placed on a threedimensional motorized stage to perform multiple samples or for a single sample to be analysed at different points.

X-ray fluorescence (XRF) and micro-particle induced X-ray Emission (PIXE) works were operated for detecting of heterogeneity of ancient bronze and silver alloys (Vasilescu et al., 2017). Hlozek and Trojek (Hlozek and Trojek, 2017) investigated silver and tin plating (such as medieval methods of producing counterfeit coins) and their characterization with using micro-X-ray fluorescence ( $\mu$-XRF). The elemental concentration work of bronze vessels from the derveni tombs of central Macedonia of the fourth century BCE were investigated by means of micro beam X-ray fluorescence ( $\mu \mathrm{XRF}$ ) technique (Katsifas et al., 2019).The surface elemental analysis was made by using a micro-XRF study for Polish silver coins (del Hoyo-Meléndez et al., 2015). Micro-XRF element mapping and EXAFS spectroscopy was used to determine distribution and speciation of arsenic around roots in a contaminated riparian floodplain soil by (Voegelin et al., 2007).

From previous studies, we see that successful results have been reported in the examination of historical samples of the micro X-ray fluorescence spectroscopy method, in the investigation of various alloys, in the analysis of paint materials and in the examination of soil materials such as rocks and sands.
In the presented study, it was aimed to evaluate the homogeneity of bimetallic alloys produced with Vaksis Thermal Evaporator system. It is known that the micro-XRF system is suitable for determining the homogeneity of metals, stratified materials, environmental and biological specimens (such as tissue, muscle etc.) and for investigation in archaeology and forensic fields. But the phenomena of determining the homogeneity of the bimetallic alloys at different concentrations is uncertain. When an alloy is fabricated, it is important to determine the elemental concentration and the homogeneity of the materials composed the alloy. Besides, it is also significant to examine the relationship between the different concentrations. In this study, the homogeneity of $\mathrm{Ag}-\mathrm{Au}$ bimetallic alloys was determined and the surfaces of the samples was mapped using micro-XRF

\section{Material and methods}

\subsection{Sampling}

The bimetallic Silver (Ag)-gold (Au) alloys are settled on glass slides by Vaksis Thermal Evaporator with the $2-3 * 10^{6}$ bar pressure in the vacuum chamber at $100 \mathrm{~nm}$ thickness approximately. Before settlement, all glass slides are cleaned by using piranha solution $\left(3 \mathrm{H}_{2} \mathrm{SO}_{4}+\right.$ $1 \mathrm{H}_{2} \mathrm{O}_{2}$ ) for three hours. After cleaning with piranha solution $\left(3 \mathrm{H}_{2} \mathrm{SO}_{4}+1 \mathrm{H}_{2} \mathrm{O}_{2}\right)$, the samples were placed in acetone and kept in an ultrasonic bath for 1 hour. Then the samples were washed with isopropanol and water, dried with nitrogen, and made ready for metal coating. The coating of Ag$\mathrm{Au}$ alloy was carried out using two different current sources in a thermal evaporator. The coating speeds of metals are calibrated with a quartz crystal microbalance detector. Since the coating speed of $\mathrm{Ag}$ is very stable and constant depending on time compared to the coating speed of $\mathrm{Au}$, only the current passing over the coating speed of Au during evaporation was changed by controlling. The samples were prepared by sputter depositing silver films of various thicknesses on a gold substrate.

\subsection{Components of experimental set-up}

The experimental system consists of a side window $\mathrm{X}$-ray tube, semiconductor detector, moving in three dimension and angle specimen table, CCD camera integrated with the optical microscope. The $\mathrm{X}$-ray tube is consisted of a molybdenum anode 50 $\mathrm{W}$ power, air-cooling system, fifty micrometer Molybdenum filter in the incident photon. The photon counting is a kind of silicon drift 
semiconductor detector (SDD) which has (D), active area $10 \mathrm{~mm}^{2}$, effective thickness 450 micrometet, 8 micrometer beryllium window, full width half maximum $(\mathrm{FWHM})=140 \mathrm{eV}$ at 5.9 $\mathrm{keV}$. All system components are controlled remotely by LabVIEW (VI) programme. The system of the micro X-ray fluorescence spectrometer was explained by Wrobel in details (Wrobel et al., 2012).

\subsection{Analysis of data}

All spectra obtained were kept in *.spe file type. There are 100 spectra totally for each $\mathrm{Ag}-\mathrm{Au}$ bimetallic alloys. All of the spectra for each sample was analysed using WinAxill analysis programme with using batch mode. The batch mode of WinAxill can provide measurement time, real time, and positions of dots in xyz coordinates, continuum, and counts of $\mathrm{K}, \mathrm{L}, \mathrm{M}$ etc. lines and deviations of lines in excel formats. In the gold and silver alloys, the $\mathrm{L}_{\alpha}$ lines of the relevant elements were used. The fit model spectrum is needed for analysing in Win Axill batch mode. And finally the homogeneities were calculated by means of $\mathrm{L}_{\alpha}$ counts using the related formulas.

\subsection{Calculation homogeneity of $\mathrm{Ag}$-Au bimetallic alloys}

Investigation of the homogeneity of $\mathrm{Au}-\mathrm{Ag}$ bimetallic alloys was performed. Four samples with different concentrations of $\mathrm{Au}$ and $\mathrm{Ag}$ elements were investigated. The purpose of this experiment was to calculate the average surface mass of silver-gold, $\mathrm{M}_{\mathrm{Ag} / \mathrm{Au}}$, and its relative uncertainty in temrs of the layer intrinsic inhomogeneity. The current specimen was counted at one thousand dots on the surface of the specimen. The radiation source was performed at $50 \mathrm{kV}$ voltage and $1 \mathrm{~mA}$ current. For each specimen, the obtained relative changing of the specimen surface mass was figured out from the set of $n$ counted dots:

$$
\begin{aligned}
& \mathrm{S}_{\text {observed }}^{2}=\frac{1}{\left(\mathrm{M}_{\mathrm{Ag}, \mathrm{Au}}\right)^{2}} \frac{\sum_{\mathrm{i}=1}^{\mathrm{n}}\left(\mathrm{M}_{\mathrm{Ag}, \mathrm{Au}, \mathrm{i}}-\mathrm{M}_{\mathrm{Ag}, \mathrm{Au}}\right)^{2}}{\mathrm{n}-1} \\
& \mathrm{M}_{\mathrm{Ag}, \mathrm{Au}}=\frac{\sum_{\mathrm{i}=1}^{\mathrm{n}} \mathrm{M}_{\mathrm{Ag}, \mathrm{Au}, \mathrm{i}}}{\mathrm{n}}
\end{aligned}
$$

The obtained changes have two important contributions: one of them is concerned the measurement methodology and other is about the sample intrinsic homogeneity (Wrobel et al., 2012).

$$
\mathrm{S}_{\text {observed }}^{2}=\mathrm{S}_{\text {method }}^{2}+\mathrm{S}_{\text {homog }}^{2}
$$

For the bimetallic alloys the surface masses at

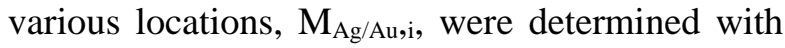
using adapting a thin specimen model. The intensity of fluorescence radiation (I) is rational to the surface mass of gold and silver $\left(\mathrm{M}_{\mathrm{Ag} / \mathrm{Au}}\right)$ :

$$
I=\int_{E_{A g, A u}}^{E_{\max }} K_{A g, A u}(E) d I_{0}(E) M_{p}=K_{A g, A u}^{\prime} M_{A g, A u}
$$

$\mathrm{K}_{\mathrm{Ag}, \mathrm{Au}}(\mathrm{E})$ is a product of $\mathrm{Au}-\mathrm{L}_{\alpha}$ and $\mathrm{Ag}-\mathrm{L}_{\alpha}$ peaks production cross-sections. This parameter includes detection efficiency. $\mathrm{dI}_{0}(\mathrm{E})$ is a relative number of incident photons with energy; $\mathrm{E}_{\mathrm{Ag}, \mathrm{Au}}$ is the energy of the gold and silver photoelectric attenuation Ledge; and $\mathrm{E}_{\max }$ is the maximum energy of the incident photons.

$$
\begin{aligned}
& I=\int_{E_{A g, A u}}^{E_{\max }} K_{A g, A u}(E) d I_{0}(E) M_{A g, A u} \frac{1-\exp \left\{-M_{A g, A u}-b(E)\right\}}{M_{A g, A u} b(E)} \\
& \cong K_{A g, A u}^{\prime} \frac{1-\exp \left\{-M_{A g, A u}-b(E)\right\}}{M_{A g, A u} b(E)} \\
& \left.b\left(E_{e f f}\right)=\right) \frac{\mu_{A g, A u}\left(E_{e f f}\right)}{\sin \varphi}+\frac{\mu_{A g, A u}\left(E_{A g, A u-l}\right)}{\sin \Psi}
\end{aligned}
$$

For the bimetallic alloys, the values of surface mass were calculated with using formula (3) for gold and silver at any location.

$$
\mathrm{M}_{\mathrm{Ag}, \mathrm{Au}, \mathrm{i}}=\frac{\mathrm{I}_{\mathrm{i}}}{\mathrm{K}_{\mathrm{Ag}, \mathrm{Au}}^{\prime}}
$$

When the expressions (4b) and (4c) are rearranged for the thick sample

$$
\mathrm{M}_{\mathrm{Ag}, \mathrm{Au} \mathrm{i}}=-\frac{1}{\mathrm{~b}\left(\mathrm{E}_{\mathrm{eff}}\right)} \ln \left[1-\mathrm{I}_{\mathrm{i}} \frac{\mathrm{bE}(\mathrm{eff})}{\mathrm{K}_{\mathrm{Ag}, \mathrm{Au}}^{\prime}}\right]
$$


$\mathrm{K}_{\mathrm{Ag}, \mathrm{Au}}$ is the sensitivity factor. The factor was computed by counting the photons of thin gold $\mathrm{Au})$ and silver $(\mathrm{Ag})$ standard samples with known surface mass.

For each location, the value of $\mathrm{K}^{\prime}{ }_{\mathrm{Ag}, \mathrm{Au}, \mathrm{i}}$ was found with the formula below:

$\mathrm{K}_{\mathrm{Ag}, \mathrm{Au}, \mathrm{i}}^{\prime}=\frac{\mathrm{I}_{\mathrm{std}, \mathrm{i}}}{\mathrm{M}_{\mathrm{Ag}, \mathrm{Au}, \mathrm{std}}}$

where $\mathrm{I}_{\text {std,i }}$ is the intensity of $\mathrm{Au}-\mathrm{L}_{\alpha}$ and $\mathrm{Ag}-\mathrm{L}_{\alpha}$ peak for interested location and $\mathrm{M}_{\mathrm{Ag}, \mathrm{Au}}$, std refers to the certified surface mass of $\mathrm{Au}$ and $\mathrm{Ag}$ in the standard specimen. The unknown gold and silver samples were excited by using X-ray photons under the same the X-ray tube current and voltage. The average value of $\mathrm{K}^{\prime}{ }_{\mathrm{Ag}, \mathrm{Au}}$ was determined with the set of a hundred measurements;

$\mathrm{K}_{\mathrm{Ag}, \mathrm{Au}}^{\prime}=\frac{\sum_{\mathrm{i}=1}^{\mathrm{n}} \mathrm{K}_{\mathrm{Ag}, \mathrm{Au}, \mathrm{i}}^{\prime}}{\mathrm{n}}$

The values of $\mathrm{K}^{\prime}{ }_{\mathrm{Ag}, \mathrm{Au}}$ the method variance arises since of the propagation of the counting statistic fluctuations through formula 5 and 6 . When estimating the expected value, assuming the Poisson distribution counting statistics, uncertainty propagation law of variable method was used. The expected relative changing of the technique for the thin specimen was determined as shown formula below

$\mathrm{S}_{\text {method }}^{2}=\frac{1}{\mathrm{~K}_{\mathrm{Ag}, \mathrm{Au}, \mathrm{i}}^{\prime} \mathrm{M}_{\mathrm{Ag}, \mathrm{Au}, \mathrm{i}}}\left(1+\frac{\mathrm{B}}{\mathrm{K}_{\mathrm{Ag}, \mathrm{Au}, \mathrm{i}}^{\prime} \mathrm{M}_{\mathrm{Ag}, \mathrm{Au}, \mathrm{i}} \mathrm{i}}\right)$

where $\mathrm{t}$ and $\mathrm{B}$ refers to the measurement duration for each point and the mean of counting numbers under the $\mathrm{Au}-\mathrm{L}_{\alpha}$ and $\mathrm{Ag}-\mathrm{L}_{\alpha}$ peak at the background.
The relative uncertainty of the layer surface mass since of its heterogeneity was determined by reorganizing formula (3):

$S_{\text {homog }}=\sqrt{S_{\text {observed }}^{2}-S_{\text {method }}^{2}}$

\subsection{Mapping}

The scanned area provides 100 measurement points. The measurement time was adjusted as 100 second for each data point. The operating parameters (such as X-ray tube current and voltage) were adjusted as $50 \mathrm{kV}$ and $1 \mathrm{~mA}$, respectively. It is not only the homogeneity mapping of the ratios but also the homogeneity mapping of the individual elements was plotted. It shows that there are specific areas where the intensities are high indicating the attendance of a particle in that bimetallic alloy.

\section{Results and discussions}

In order to calculate the homogeneity, measurements were taken from different hundred points on the sample in the current work. The experimental measurement methodology $S_{\text {method }}^{2}$, the sample intrinsic homogeneity $S_{\text {homogeneity }}$ and $S_{\text {observed }}^{2}$ values for $\mathrm{Ag}$-Au have been used for calculation the $\mathrm{Ag} / \mathrm{Au}$ ratios. The obtained $\mathrm{Ag} / \mathrm{Au}$ ratios are in good agreement between current production results. Production concentration values, number of measurement points and homogeneity ratios are shown in Table 1 . When looking at table 1 it is seen that the production ratios of $\mathrm{Ag} / \mathrm{Au}$ are in good agreement with Shomogeneity values for different ratios of bimetallic alloys.

Table 1. Results of homogeneity testing and concentration ratios of Au and Ag in bimetallic alloys with micro$\mathrm{XRF}$

\begin{tabular}{|c|c|c|c|c|c|c|c|c|}
\hline Samples & $\begin{array}{c}\text { Ratios of } \\
\text { Concentrations }\end{array}$ & Elements & $\begin{array}{l}\text { Element } \\
\text { Lines }\end{array}$ & $\begin{array}{c}\text { Number of } \\
\text { Points }\end{array}$ & $\begin{array}{c}\mathbf{S}_{\text {measured }} \\
{[\%]}\end{array}$ & $\begin{array}{c}\text { Smethod } \\
{[\%]}\end{array}$ & $\begin{array}{c}\text { Shomog } \\
{[\%]}\end{array}$ & $\mathbf{A g} / \mathbf{A u}$ \\
\hline \multirow[t]{2}{*}{ S1 } & \multirow[t]{2}{*}{$1: 1$} & \multirow{6}{*}{$\mathrm{Ag}-\mathrm{Au}$} & $\mathrm{Au} \mathrm{L} \mathrm{L}_{\alpha}$ & 100 & 7.93 & 2.36 & 7.57 & 0.90 \\
\hline & & & $\operatorname{Ag~} \mathrm{L}_{\alpha}$ & 100 & 8.49 & 1.00 & 8.43 & \\
\hline \multirow[t]{2}{*}{ S2 } & \multirow[t]{2}{*}{$1: 2$} & & $\mathrm{Au} \mathrm{L} \mathrm{L}_{\alpha}$ & 100 & 10.06 & 0.40 & 10.05 & 2.12 \\
\hline & & & $\operatorname{Ag} L_{\alpha}$ & 100 & 4.73 & 0.13 & 4.73 & \\
\hline \multirow[t]{2}{*}{ S3 } & $1: 2.5$ & & $\mathrm{Au} \mathrm{L} \mathrm{L}_{\alpha}$ & 100 & 10.95 & 0.34 & 10.94 & 2.66 \\
\hline & & & $\operatorname{Ag} L_{\alpha}$ & 100 & 4.12 & 0.11 & 4.11 & \\
\hline
\end{tabular}

The ratios were calculated between $4.0 \%-9.0 \%$ and $7 \%-11 \%$ with using $\mathrm{Ag}$ and $\mathrm{Au} \mathrm{L}_{\alpha}$ lines, respectively. It is seen that the concentration ratios vary between 1 and 2.5 at the same table. The margin of error in the present experiment is due to the photon counting statistics. Surely, errors exist during the sample production phase. The initial values were adjusted to obtain the final concentration value for the production process. 
Table 2. Results of homogeneity testing and concentration ratios of Au and Ag in bimetallic alloys with micro$\mathrm{XRF}$

\begin{tabular}{|c|c|c|c|c|c|}
\hline $\begin{array}{ll}\text { Ratios } & \text { of } \\
\text { Concentrations }\end{array}$ & $\begin{array}{l}\text { Average } \mathrm{Au} \mathrm{L}_{\alpha} \\
\text { Photons }\end{array}$ & $\begin{array}{ll}\text { Average } \quad \mathrm{Au} & \mathrm{L}_{\alpha} \\
\text { Photon Errors } & \end{array}$ & $\begin{array}{l}\text { Average } \mathrm{Ag} \mathrm{L}_{\alpha} \\
\text { Photons }\end{array}$ & $\begin{array}{l}\text { Average } \mathrm{Ag} \\
\text { Photon Errors }\end{array}$ & $\begin{array}{l}\text { Number of } \\
\text { Points }\end{array}$ \\
\hline $\begin{array}{l}1-1.0 \\
\end{array}$ & 1041.13 & 24.58 & 2357.21 & 23.66 & 100 \\
\hline $1-2.0$ & 1047.82 & 15.90 & 2373.62 & 14.49 & 100 \\
\hline $1-2.5$ & 1008.76 & 4.00 & 2694.43 & 3.61 & 100 \\
\hline
\end{tabular}

Homogeneity maps of bimetallic alloys were compared with homogeneity maps of pure Ag and Au elements in Figure 1.
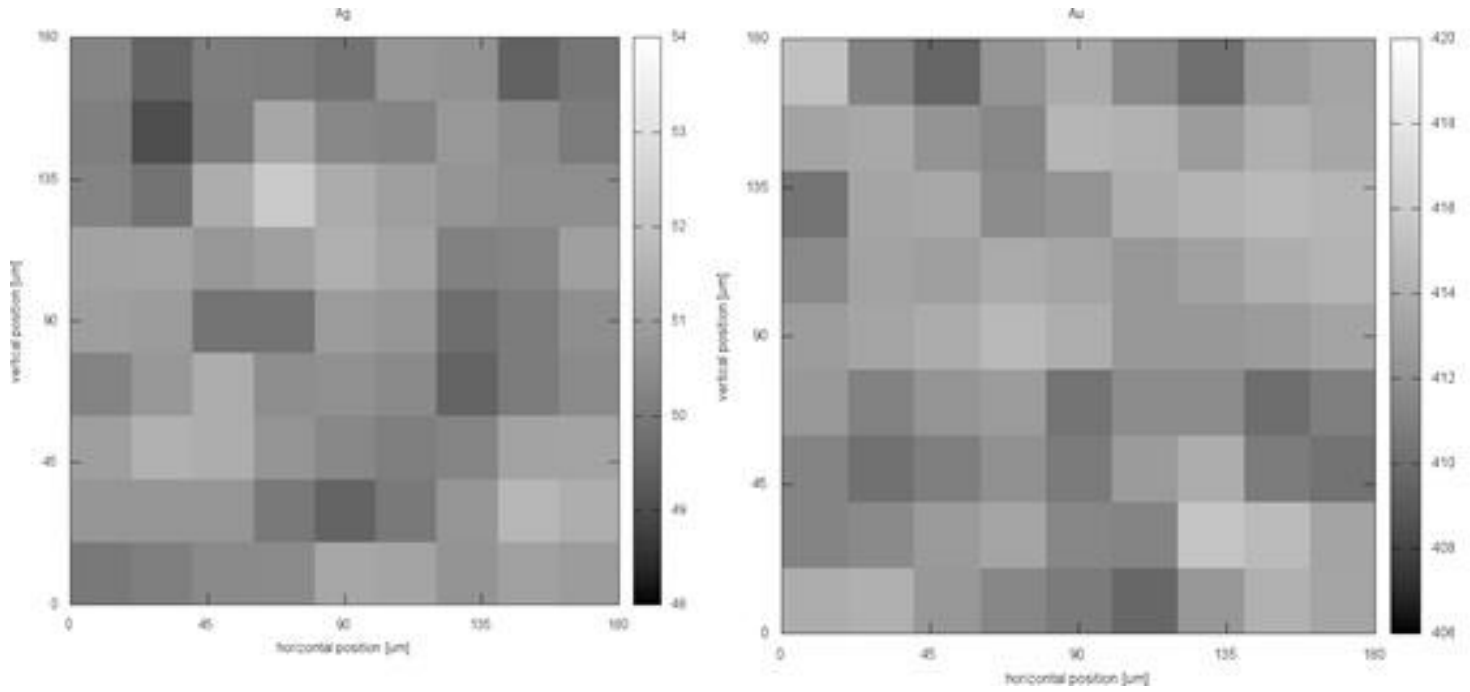

Figure 1. Maps of homogeneity for ratios Ag and Au compositions for each sample.

As can be seen in Figure 2, it was observed that a good homogeneity was obtained for the pure Ag and Au samples. It is seen that the production system and micro-XRF system are suitable for use in bimetallic alloys.
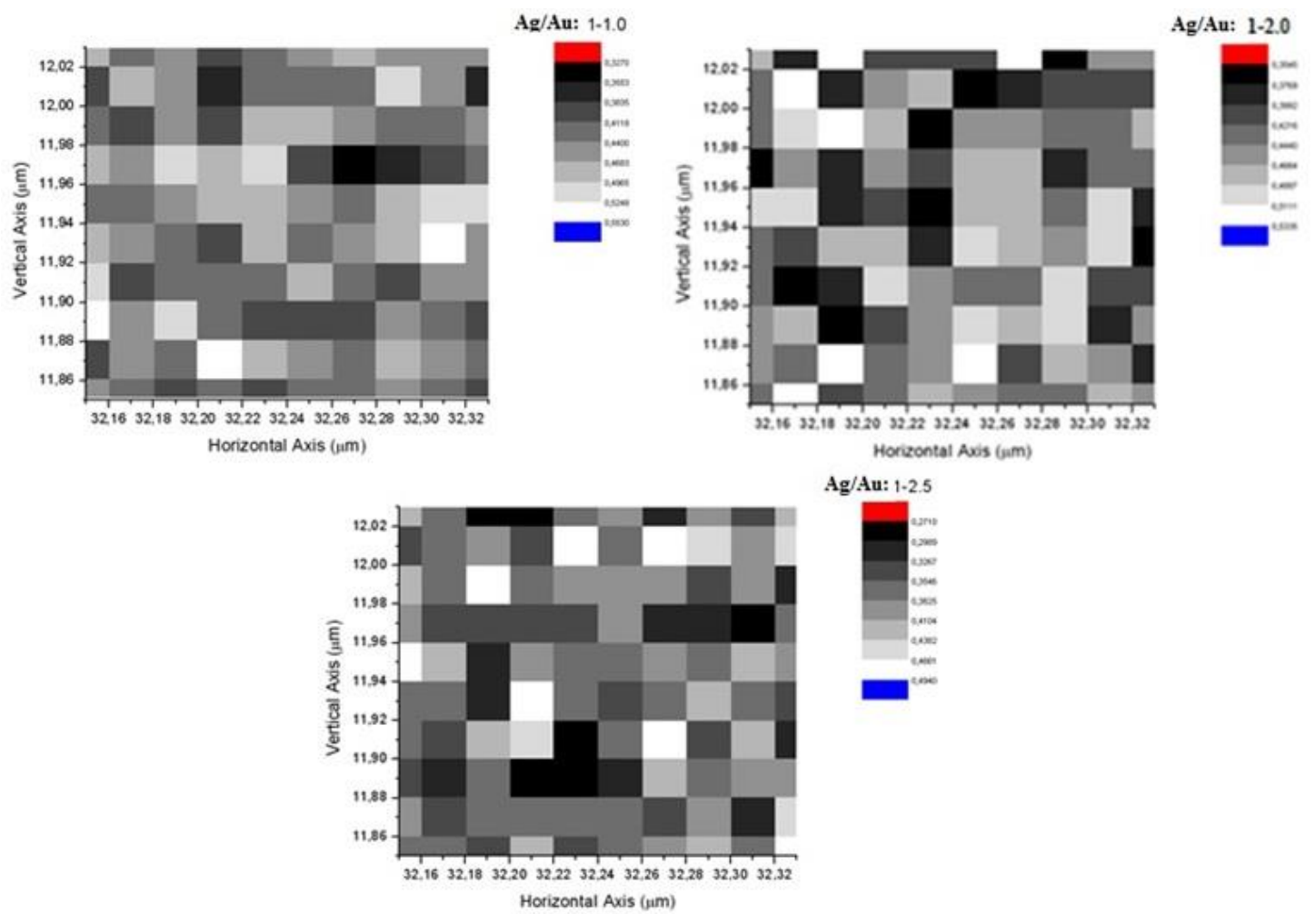

Ag/Au: 1.2 .5

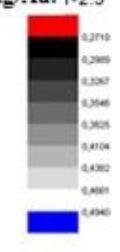

Figure 2. Maps of homogeneity for ratios $\mathrm{Ag}$ and $\mathrm{Au}$ compositions for each sample. 
The maps on figure 2 were obtained using the compositions of silver and gold, which are the constituents of the bimetallic alloys. All grey level scale bar values in unit less and the axes (vertical and horizontal) are scaled in micrometre. The figure 2 illustrates map of the ratios of silver and gold, which are the constituents of the bimetallic alloys. The Ag deposition rate was kept constant compared to $\mathrm{Au}$ during production. The $\mathrm{Ag} / \mathrm{Au}$ labels in the figure have been corrected as $\mathrm{Ag} / \mathrm{Au}$. Thus, it is seen that as the gold ratio increases, the white places increase relatively.

\section{Conclusion}

The aim of that study is to reveal the capability of micro-XRF technique for determining both homogeneity and elemental analysis in bimetallic alloys. When considering the current values, these results in this current work are also in a good agreement with production values. It is seen that the homogeneity values calculated using micro beam XRF confirmed the production values. This shows that the Vaksis Thermal Evaporator system provides sufficient homogeneity for production of $\mathrm{Ag}-\mathrm{Au}$ bimetallic alloys. Micro beam XRF spectrometer is an adequate technique for the bimetallic alloys not only to test homogeneity but also to determine the gold and silver concentrations.

\section{Acknowledgement}

The author acknowledge the support by 2016/547YLS project made in Kahramanmaras Sutcu Imam University USKIM (Kahramanmaras TURKEY). The author also thanks to Prof. Dr. Marek LANKOSZ and Dr. Pawel WROBEL from AGH UST (Cracow, Poland) and Prof. Dr. Omer SOGUT from KSU (Kahramanmaras, Turkey) for their support.

\section{References}

del Hoyo-Meléndez, J.M., Świt, P., Matosz, M., Woźniak, M., Klisińska-Kopacz, A. and Bratasz, Ł. (2015). Micro-XRF analysis of silver coins from medieval Poland. Nuclear Instruments and Methods in Physics Research Section B: Beam Interactions with Materials and Atoms 349, 6-16. https://doi.org/10.1016/j.nimb.2015.02.018

Hlozek, M. and Trojek, T. (2017). Silver and tin plating as medieval techniques of producing counterfeit coins and their identification by means of microXRF. Radiation Physics Chemistry 137, 234237. https://doi.org/10.1016/j.radphyschem.2016.08. 013
Ispasoiu, R.G., Balogh, L., Varnavski, O.P., Tomalia, D.A. and Goodson III, T. (2000). Large optical limiting from novel metal- dendrimer nanocomposite materials. Journal of the American Chemical Society 122, 11005-11006. https://doi.org/10.1021/ja0015646

Jana, N.R. and Peng, X. (2003). Single-phase and gramscale routes toward nearly monodisperse $\mathrm{Au}$ and other noble metal nanocrystals. Journal of the American Chemical Society 125, 14280-14281. https://doi.org/10.1021/ja038219b

Kanngiesser, B., Malzer, W., Rodriguez, A.F. and Reiche, I. (2005). Three-dimensional micro-XRF investigations of paint layers with a tabletop setup. Spectrochimica Acta Part B: Atomic Spectroscopy 60, 41-47. https://doi.org/10.1016/j.sab.2004.10.012

Katsifas, C., Touloumzidou, A. and Zachariadis, G. (2019). Compositional study of bronze vessels from the Derveni tombs of central Macedonia of the fourth century bce using energy-dispersive micro-X-ray fluorescence (ED $\mathrm{XXRF}$ ) spectrometry. Archaeometry 61, 1313-1332. https://doi.org/10.1111/arcm.12486

Lin, X.Y., Wang, Z.H., Sun, T.X., Pan, Q.L. and Ding, X.L. (2008). Characterization and applications of a new tabletop confocal micro X-ray fluorescence setup. Nuclear Instruments and Methods in Physics Research Section B: Beam Interactions with Materials and Atoms 266, 2638-2642.

https://doi.org/10.1016/j.nimb.2007.12.064

Mantouvalou, I., Lange, K., Wolff, T., Grotzsch, D., Luhl, L., Haschke, M., Hahn, O. and Kanngiesser, B. (2010). A compact 3D micro Xray fluorescence spectrometer with $\mathrm{X}$-ray tube excitation for archaeometric applications. Journal of Analytical Atomic Spectrometry 25, 554-561.

Mulvaney, P., Giersig, M. and Henglein, A. (1993). Electrochemistry of multilayer colloids: preparation and absorption spectrum of goldcoated silver particles. The Journal of Physical Chemistry 97, 7061-7064. https://doi.org/10.1021/j100129a022

Nakano, K. and Tsuji, K. (2010). Development of laboratory confocal 3D-XRF spectrometer and nondestructive depth profiling. Journal of Analytical Atomic Spectrometry 25, 562-569. https://doi.org/10.1039/B916974A

Sun, Y. and Xia, Y. (2002). Shape-controlled synthesis of gold and silver nanoparticles. Science 298, 2176-2179. https://doi.org/10.1126/science.1077229 
Tsuji, K. and Nakano, K., (2007). Development of confocal 3D micro-XRF spectrometer with dual Cr-Mo excitation. X-Ray Spectrometry 36, 145 149. https://doi.org/10.1002/xrs.957

Vasilescu, A., Constantinescu, B., Stan, D., Talmatchi, G. and Ceccato, D., (2017). XRF and microPIXE studies of inhomogeneity of ancient bronze and silver alloys. Nuclear Instruments and Methods in Physics Research Section B: Beam Interactions with Materials and Atoms 406, 302308. https://doi.org/10.1016/j.nimb.2017.02.019

Voegelin, A., Weber, F.-A. and Kretzschmar, R., (2007). Distribution and speciation of arsenic around roots in a contaminated riparian floodplain soil: Micro-XRF element mapping and EXAFS spectroscopy. Geochimica et
Cosmochimica Acta 71, 5804-5820. https://doi.org/10.1016/j.gca.2007.05.030

Wang, R., Yang, J., Zheng, Z., Carducci, M.D., Jiao, J. and Seraphin, S., (2001). Dendron-controlled nucleation and growth of gold nanoparticles. Angewandte Chemie International Edition 40, 549-552. https://doi.org/10.1002/15213773(20010202)40:3<549::AIDANIE549>3.0.CO;2-P

Wrobel, P., Czyzycki, M., Furman, L., Kolasinski, K., Lankosz, M., Mrenca, A., Samek, L. and Wegrzynek, D., (2012). LabVIEW control software for scanning micro-beam X-ray fluorescence spectrometer. Talanta 93, 186-192. https://doi.org/10.1016/j.talanta.2012.02.010 